\title{
Maxwell 型粘性ダンパーの固有值に基づく配置計画 STUDY ON DAMPING DISTRIBUTION OF MAXWELL-TYPE VISCOUS DAMPERS BASED ON EIGENVALUE ANALYSIS
}

\author{
石 垣 秀 典* \\ Hidenori ISHIGAKI
}

\begin{abstract}
Eigenvalue analysis considering Maxwell model is proposed in this study, so as to compute properties and distribution of viscous dampers automatically. A real number eigenvalue of Maxwell model shows dynamic characteristic of viscous damper. If the real number eigenvalue becomes equal to a natural circular frequency of analysis model, the model will have the maximum energy dissipation to the vibration mode. In this paper, viscous damper distribution of a frame structure has been computed by the proposed method. The results have showed that the structure has the highest viscous damping factor to the design vibration mode.
\end{abstract}

Keywords: Passive control, Viscous damper, Viscous Damping Factor, Complex eigenvalue analysis パッシブ制振，粘性ダンパー，粘性減衰定数，複素固有值解析

1. 序

近年、高層建築物の長周期地震動対策などをはじめとして、さま ざまな形での粘性系ダンパーの利用が増加しており、そのような制 振構造物の性能評価法やダンパーの配置方法に関する研究も様々に 展開されている。

それら多くの研究の中で、一般的な構造物の層間に Maxwell モデ ルで模擬される粘性型ダンパーの設置を対象にしたものとしては、 実地震動に対する応答低減効果を考慮に入れた 1 質点系の性能曲線 を基にして、各層の剛性分布などに応じてダンパーを配置する方法 1)や、システムの伝達関数の定点をなるべく小さくするようにダン パーの配置を決定する方法 2)3、 あるいは白色雑音入力に対する定常 ランダム応答解析に基づいて構造物の減衰性能が最大となるように ダンパーを配置する研究 4 なよ゙が挙げられる。

さて、それらの研究では質点一ば初系モデルを基本として行われ ているものが多い。そのため、実設計で用いられている立体骨組モ デルから質点系モデルへの縮約、あるいは質点系モデルで高さ方向 の分布を決定した後に平面配置を検討する際には、モデル変換をす る必要がある。その作業の際には、モデル化による差異がなる心゙く 生じないように配慮する必要があり、そのような振動モデルの違い による影響に着目した研究 5)6 も行われている。粘性型ダンパーの効 果を過大に評価しないためにも重要な検討項目のひとつである。 そのような問題を解決するためには、構造設計に用いる骨組モデ
ルをそのまま用いて、ダンパー設置位置周辺の骨組剛性の影響を含 めた部材レベルでの設計方法を構築する必要があるが、この領域で の研究は未だ数少ない。その一例としては西村の研究 7)が挙げられ、 骨組内部に設置した減衰装置の効果を、実固有值解析から得られる 固有振動数の変化を基に推定する方法を提案している。減衰性能を 過大に評価し過ぎないような設計法が必要であるという研究目的は、 本研究と同様であり部材レベルでの検討結果が報告されている。し かし、実固有值解析を用いた手法を展開しており、複素固有值解析 から得られるダンパーの特性值を利用する本研究とは、計算方法が 大きく異なっている。

一方で、制振設計の実務における現状は、設計用資料等に載って いる式や図表で概略の装置仕様を仮決定し、時刻歴応答解析によっ て応答值を設計目標内に収めるための収斂作業が行われている場合 が多いと思われる。そのような状況の中で、本研究ではそのような 反復作業を軽減し、かつ粘性ダンパーのエネルギー吸収を適正に判 断して設計が行えるような計算方法を提案することを目的としてい る。そして本論においては、粘性ダンパーを設置した構造物の粘性 減衰定数をなるべく大きくするように、ダンパーの減衰係数や配置 位置を決定するための手法を提案する。

その手法を実践するにあたっては反復計算を伴うが、その指標と して用いる值は、Maxwell モデルを含んだ固有值問題 8)から得られ るダンパーの特性值を利用している。既往の研究 8)では、このダン 
パーの特性值を利用して、粘性ダンパー取付部材の岡性不足に起因 する減衰効果の損失状況を判断する指標として用いているが、本研 究においては、その值をダンパーの減衰係数を決定する指標として 利用することを試みたものである。この特性值は固有值問題から得 られるため、実際の設計で用いている骨組モデルをそのまま利用す ることができ、実務にも馴染みやすい手法であると考えている。本 論では、平面骨組モデルを対象にして、仮定したダンパー配置でシ ステムの粘性減衰定数が最大となるような減衰係数を求める方法、 および最も減衰効果の高いダンパー配置を決定する方法について検 討を行っている。なお、検討を行うにあたっては、付与される粘性 減衰はダンパー要素のみとし、一般的に剛性比例型などで付与され ている構造減衰は考慮しないことにする。また、ダッシュポット部 分の減衰係数は線形として扱う。

本論文の具体的な内容について述べる。まず、ダンパーへの入力 変位を考慮に入れた複素固有值問題から、システム全体の固有振動 数、減衰定数および Maxwell 要素部分の特性を表す 1 次系の固有值 を抽出する方法について説明する。次に、平面骨組モデルを対象に 仮定されたダンパー配置において、指定した振動モードの粘性減衰 定数を最大にするための減衰係数を算出する方法を提案し、精度検 証を行っている。

\section{Maxwel| 型減衰要素を含む構造物の固有値問題}

本章では、まず Maxwell 型減衰要素を含む構造物モデルを対象に した固有值問題について整理しておく。Fig.1 に示すようなある構 造物の一部に設置された Maxwell 型減衰要素の要素軸方向の運動 方程式は、ダッシュポットへの入力変位を考慮に入れて(1)式のよう に表せる。Fig.1 において、ダッシュポットと直列結合するばねと の結合点に質量は設けていない。その理由としては、これらの要素 が粘性ダンパーの加力実験結果等から求められた内部剛性と隇衰係 数を表現する要素として扱っているためである。これに接続部材を 付加する場合には、Fig.1の節点 $i$ または節点 $j$ に接続部材と質量を 設ければ良い。また、既往の研究 8)で述べられているように、結合 点に質量を定義せずにダンパー部分を 1 次遅れ要素として扱う事に より、このダンパー要素が構造物全体の減衰性能に及ぼす影響度を 明確に把握することができる。

この要素行列を構造物全体のマトリックスに加えることにより、 地動入力 $\ddot{z}$ に対する Maxwell 要素を含んだ構造物全体の状態方程 式が(2)式のように構成できる。なお、式中で $\mathrm{K}_{\mathrm{d}} 、 \mathrm{~K}_{\mathrm{d} 1} 、 \mathrm{~K}_{\mathrm{d} 2}$ および $\mathrm{C}_{\mathrm{d}}$ は、ダンパー設置数分の Maxwell 要素のば㓥郕と減衰係数を、

(1)式を参考にしてまとめた行列を表している。

そして $\boldsymbol{\delta}=\mathbf{r} e^{\lambda t}$ とすれば、固有值問題は（3)式のように構成でき、 その(3)式を解くことにより、(4)式に示すような共役複素数 $\lambda_{j}, \bar{\lambda}_{j}$ と 実数解 $\lambda_{k}{ }^{\prime}$ の固有值が求められる。

共役複素数の固有值は、構造物全体の $j$ 次固有值であるため、通常 の複素固有值問題と同様に、共役複素数の和と積よりシステム全体 の $j$ 次粘性減衰定数 $h_{j}$ および固有円振動数 $\omega_{j}$ が求められる。システ ムの振動数と減衰定数の情報だけが必要であれば、この共役複素数 の固有值のみを利用すれば良いが、実数の固有值 $\lambda{ }_{k}$ にはダンパーに 関する情報が固有值問題を介して格納されているため、本研究では その情報を有効に活用する。

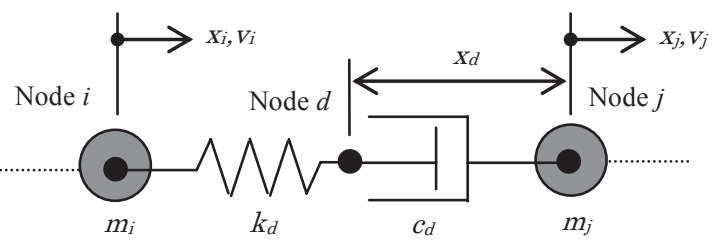
$m_{i}, m_{j} \quad$ : Mass
$k_{d} \quad:$ Stiffness of Maxwell damper
$c_{d} \quad$ : Viscous damping of Maxwell damper
$V_{i}, V_{j}:$ Nodal velocity
$\boldsymbol{x}_{i}, \boldsymbol{x}_{j}$ : Nodal displacement
$x_{d} \quad$ : Displacement of dashpot

Fig. 1 Analytical model of Maxwell damper

$$
\begin{aligned}
& {\left[\begin{array}{ccc}
\mathbf{M}_{\mathbf{s}} & & \\
& \mathbf{I} & \\
& & c_{d}
\end{array}\right]\left\{\begin{array}{c}
\dot{\mathbf{v}} \\
\dot{\mathbf{x}} \\
\dot{x}_{d}
\end{array}\right\}+\left[\begin{array}{lll} 
& \mathbf{K}_{\mathbf{d}} & \mathbf{k}_{\mathbf{d}} \\
\text { ここで、 } & & \\
& \mathbf{k}_{\mathbf{d}}{ }^{\mathbf{T}} & k_{d}
\end{array}\right]\left\{\begin{array}{c}
\mathbf{v} \\
\mathbf{x} \\
x_{d}
\end{array}\right\}=0 } \\
& \mathbf{M}_{\mathbf{s}}=\left[\begin{array}{ll}
m_{i} & \\
& m_{j}
\end{array}\right] \quad \mathbf{K}_{\mathbf{d}}=\left[\begin{array}{cc}
k_{d} & -k_{d} \\
-k_{d} & k_{d}
\end{array}\right] \\
& \mathbf{I}=\left[\begin{array}{ll}
1 & \\
& 1
\end{array}\right] \mathbf{k}_{\mathbf{d}}=\left\{\begin{array}{c}
-k_{d} \\
k_{d}
\end{array}\right\}
\end{aligned}
$$$$
\dot{\boldsymbol{\delta}}=\mathbf{A} \boldsymbol{\delta}-\tilde{\mathbf{i}} \ddot{z}
$$$$
\text { ここで、 }
$$$$
\boldsymbol{\delta}=\left\{\begin{array}{c}
\mathbf{v} \\
\mathbf{d} \\
\mathbf{x}_{\mathbf{d}}
\end{array}\right\} \quad \widetilde{\mathbf{i}}=\left\{\begin{array}{c}
\mathbf{i} \\
\mathbf{0} \\
\mathbf{0}
\end{array}\right\} \quad \mathbf{i}=\left\{\begin{array}{c}
1 \\
\vdots \\
1
\end{array}\right\}
$$$$
\mathbf{A}=\left[\begin{array}{ccc}
\mathbf{0} & -\mathbf{M}^{-1}\left(\mathbf{K}_{\mathbf{f}}+\mathbf{K}_{\mathrm{d}}\right) & -\mathbf{M}^{-1} \mathbf{K}_{\mathrm{d} 1} \\
\mathbf{I} & \mathbf{0} & \mathbf{0} \\
\mathbf{0} & -\mathbf{C}_{d}{ }^{-1} \mathbf{K}_{\mathrm{d} 1}{ }^{\mathrm{T}} & -\mathbf{C}_{d}^{-1} \mathbf{K}_{\mathrm{d} \mathbf{2}}
\end{array}\right]
$$

M : Mass matrix of frame structure

$\mathbf{K}_{\mathbf{f}}$ : Stiffness matrix of frame structure

$\mathbf{K}_{\mathbf{d}}, \mathbf{K}_{\mathrm{d} 1}, \mathbf{K}_{\mathrm{d} 2}$ : Stiffness matrix of Maxwell damper

$\mathbf{C}_{\mathbf{d}}$ : Damping matrix of Maxwell damper

v : Velocity vector

d : Displacement vector

$\mathbf{x}_{\mathbf{d}}$ : Displacement vector of dashpot

$$
[\mathbf{A}-\mathbf{I} \lambda] \mathbf{r}=\mathbf{0}
$$

$$
\begin{aligned}
& \lambda_{j}=-h_{j} \omega_{j}+i \omega_{j} \sqrt{1-h_{j}^{2}} \\
& \bar{\lambda}_{j}=-h_{j} \omega_{j}-i \omega_{j} \sqrt{1-h_{j}^{2}} \\
& \lambda_{k}{ }^{\prime}=-h_{M k, j} \omega_{j} \\
& h_{M k, j}=\frac{\left|\lambda_{k}{ }^{\prime}\right|}{\omega_{j}}
\end{aligned}
$$


その実数固有值 $\lambda_{k}$ に関しては、ダンパーの設置数だけ求められ、 (5)式で示すようにその值を $j$ 次固有円振動数 $\omega_{j}$ で除す事により、無 次元化された特性值 $h_{M k, j}$ を抽出することができる。そして、その特 性值 $h_{M k, j}$ の大きさを判断することにより、 $j$ 次振動モードに対する ダンパーの効果を把握する事が可能となる。既往の研究 8)からは、 hMk,jが 1 よりも大きいほど Maxwell 要素のばねの影響が少なくなり、 効率的なエネルギー吸収を期待できる。 $h_{M k, j}$ が 1 よりも小さい場合 には Maxwell 要素のばねの影響が多くなり、エネルギー吸収の効率 は悪くなってくる。そして $h_{M k, F}=1$ となった場合には、対象とするモ ードの振動数と実数固有值が一致し、そのモードに対して最もエネ ルギー吸収効果が高い状態となる。このような実数解 $\lambda{ }_{k}{ }^{\prime}$ の扱いにつ いては、次節で構造物モデルを例題として取り上げて具体的に説明 する。また、刺激関数の誘導については、既往の文献 8 )に述べられて いるのでここでは省略する。

\section{3. 平面骨組モデルによる解析}

\section{1 解析モデル}

本節では、前節で述べた複素固有值解析を平面骨組モデルに適用 してみる。解析に用いた骨組モデルを Fig. 2 に示す。鉄骨フレーム を想定した 15 層のモデルとしており、 1 層の階高は $6 \mathrm{~m}$ でそれ以外 の層は全て $4 \mathrm{~m}$ としている。柱および梁の断面 2 次モーメントを Table 1 に示寸。なお、梁の軸方向剛性は剛として扱い、質量は各 層とも 100ton とし、各質点に分散させている。非減衰の固有值解 析から得られた水平方向の刺激関数を Fig. 2 に示寸が、水平方向の 固有周期は 1 次が 1.60 秒、 2 次が 0.54 秒、 3 次が 0.31 秒の值とな った。
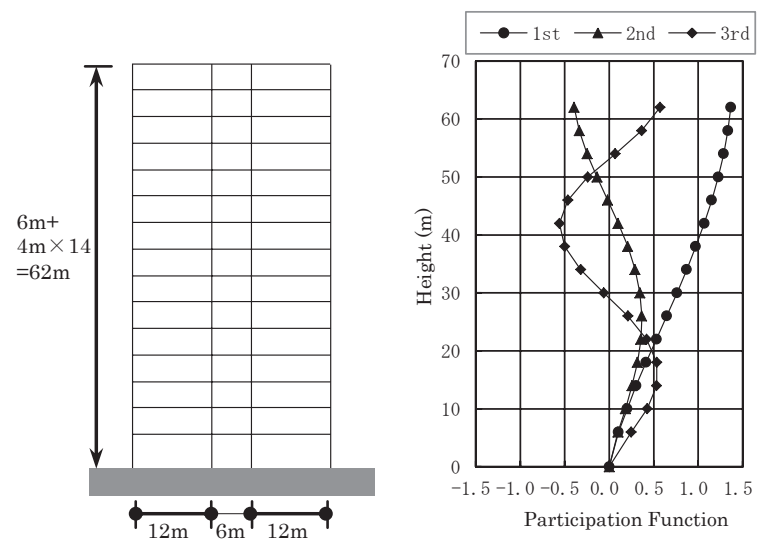

Fig. 2 Analytical model

Table 1 Properties of members

\begin{tabular}{|c|c|c|c|}
\hline \multirow{2}{*}{ Floor } & \multicolumn{2}{|c|}{ Columns } & beams \\
\cline { 2 - 4 } & $\begin{array}{c}\text { Cross sectional } \\
\text { area } \\
\left(\mathrm{m}^{2}\right)\end{array}$ & $\begin{array}{c}\text { Moment of } \\
\text { inertia } \\
\left(\mathrm{m}^{4}\right)\end{array}$ & $\begin{array}{c}\text { Moment of } \\
\text { inertia } \\
\left(\mathrm{m}^{4}\right)\end{array}$ \\
\hline $13 \sim 15$ & 0.06 & 0.0035 & 0.0040 \\
\hline $10 \sim 12$ & 0.07 & 0.0045 & 0.0040 \\
\hline $7 \sim 9$ & 0.08 & 0.0060 & 0.0040 \\
\hline $4 \sim 6$ & 0.09 & 0.0080 & 0.0040 \\
\hline $1 \sim 3$ & 0.10 & 0.0100 & 0.0050 \\
\hline
\end{tabular}

\section{2 粘性ダンパーを設置した場合の減衰特性}

本節では、まず骨組に粘性ダンパーを設置して、そのダンパー特 性が変化した場合に、構造物の粘性減衰定数がどのような变化を示 すのかを調べておくことにする。ダンパーの設置位置としては、

Fig.2 のモデルの中央スパンの 1 層、 8 層および 15 層とした。実設 計における配置箇所と比較すると少ないかもしれないが、各ダンパ 一に要求される特性の差異をなるべく明確に把握する目的もあり、 このような配置とした。設置したダンパーの内部剛性 $k_{d}$ と減衰係数 $c_{d}$ の值を Table 2 に示寸。解析方法としては、Table 2 の各ダンパー の内部剛性 $k_{d}$ を固定值とし、減衰係数を Table 2 の值の $n$ 倍 ( $n=1 \sim 30)$ に変化させた時の構造物の粘性減衰定数の変化を求める 形式で行った。なお、ここでは取付部材は考慮せずに、層間の水平 相対速度および变位に作用するように設置した。また、減衰係数の 分布としては、 $A_{i}$ 分布から求めた設計用層せん断力分布に近くなる ように設定した Case1、その比較として 3 層とも同じ值とした Case2 の 2 種類を設定した。Case1の粘性減衰定数を求めた結果を Fig. 3 に、Case 2 の結果を Fig.4 に示す。全体の粘性減衰定数の変化 は良く表現されており、このような試行錯誤的な方法でも減衰定数 のピークを概ね把握できることが分かる。

両図の比較から、 1 次 3 次の粘性減衰定数の最大值に関しては 概放同じであり、減衰定数の最大值は内部剛性の大きさに依存する ことがあらためて分かる。次に、この解析で得られるダンパーの特 性を示寸実数固有值の絶対值 $\left|\lambda k_{k}\right|$ と 1 次から 3 次までの固有円振 動数 $\omega_{1} \sim \omega_{3}$ の変化を調べた結果を Fig. 5 および Fig.6 に示す。両 図に記されている固有值 $\lambda_{k}{ }^{\prime}$ は、ダンパー設置数と同じ数だけ求め られ、算出された順に添え字 1 3 3 を付けてある。両図から、| $\lambda_{k}{ }^{\prime} \mid$ は減衰係数の増加とともに零に漸近していることが分かる。

\section{Table 2 Properties of Maxwell dampers}

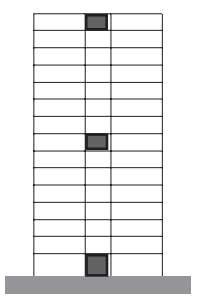

\begin{tabular}{|c|c|c|c|}
\hline \multirow{2}{*}{ Floor } & \multirow{2}{*}{$\begin{array}{c}\text { Stiffness } \\
k_{d}(\mathrm{kN} / \mathrm{m})\end{array}$} & \multicolumn{2}{|c|}{$\begin{array}{c}\text { Damping Coefficient } \\
c_{d}(\mathrm{kN} \cdot \mathrm{sec} / \mathrm{m})\end{array}$} \\
\cline { 3 - 4 } & & Case1 & Case2 \\
\hline 15 & $1.0 \times 10^{5}$ & 500 & 2500 \\
\hline 8 & $3.0 \times 10^{5}$ & 1500 & 2500 \\
\hline 1 & $5.0 \times 10^{5}$ & 2500 & 2500 \\
\hline
\end{tabular}
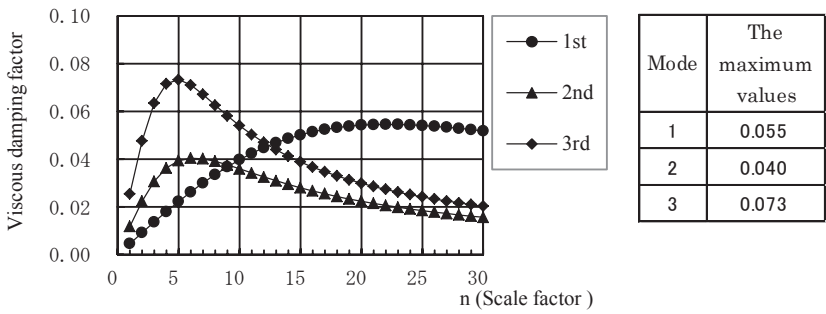

Fig. 3 Modal viscous damping factor (Case1)
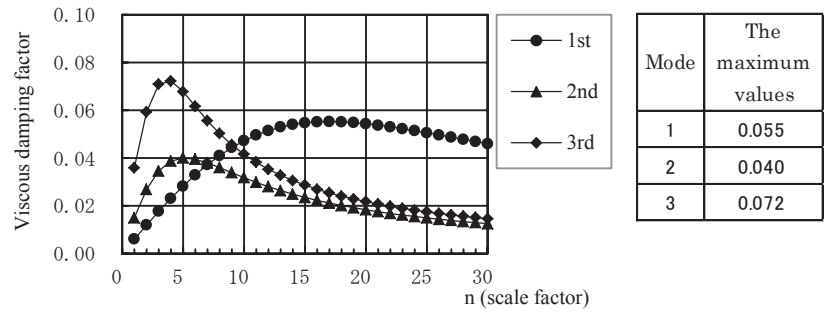

Fig. 4 Modal viscous damping factor (Case2) 


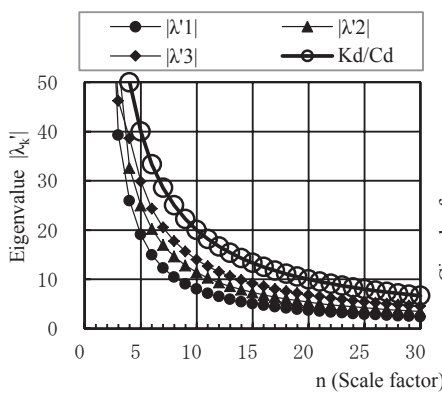

(a) $\left|\lambda_{k}{ }^{\prime}\right|$

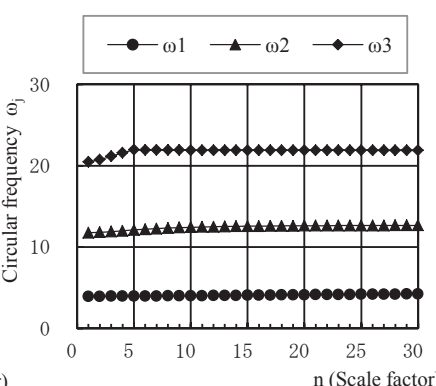

(b) $\omega_{j}$

Fig. 5 Eigenvalues $\lambda_{k}{ }^{\prime}$ and natural circular frequency $\omega_{j}$ (Case1)

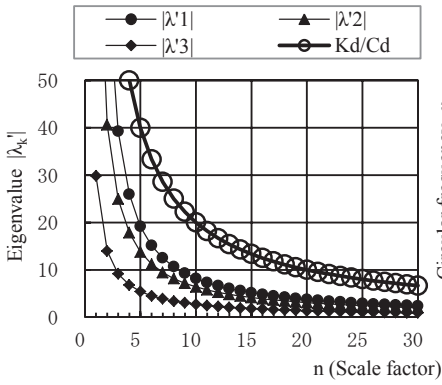

(a) $\left|\lambda_{k}{ }^{\prime}\right|$

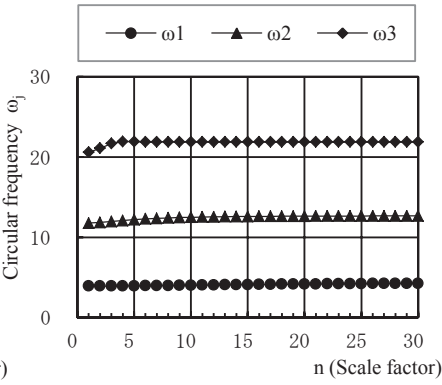

(b) $\omega_{j}$

Fig. 6 Eigenvalues $\lambda_{k}{ }^{\prime}$ and natural circular frequency $\omega_{j}$ (Case2)

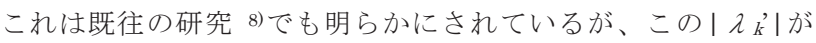
Maxwell 型ダンパーの特性である $k_{d} / c_{d}$ の比率を反映したもので あり、そのダンパーの内部剛性 $k_{d}$ に、設置した構造物の部材剛性の 影響等が加味されて固有值問題の結果として求められたものである。 したがって、減衰係数 $c_{d}$ のみを増加させていくと固有值は零に漸近 するという性質を有している。また、この| $\lambda_{k}{ }^{\prime} \mid$ はダンパーの 1 次 遅れ系の時定数の逆数に相当し、絶対值が大きいほどインパルス忘 答における応答収束時間は早くなるという特性を表す值でもある。 比較のために、その比 $\mathrm{n}$ 率 $k_{d} / c_{d}$ を Fig. 5 および Fig.6 に併せて記 す。Case1 の結果である Fig.5 では 3 基とも同じ比率であるが、 Case2 の結果である Fig.6 では設置層によって異なる值となるため、 Fig.6 には代表として 1 層のダンパーの值を示した。固有值 $\left|\lambda k_{k}^{\prime}\right|$ の值と比較すると、いずれのケースもダンパーの $k_{d} / c_{d}$ のほうが大 きな値となっていることが分かる。これは、前述したようにダンパ 一周辺フレームの剛性の影響が $k_{d}$ に反映された結果として、 $k_{d} / c_{d}$ の值が小さくなって、固有值 $\lambda k_{k}$ として抽出されてきたからである。 次に、その $\lambda k_{k}^{\prime}$ 固有円振動数で除すことによって求められる $h_{M k, j}$ の值について調べてみる。Fig.7 および Fig.8 に示した図は、 Fig.5 および Fig.6 に示した $\left|\lambda_{k}\right|$ を 1 次〜3 次の固有円振動数 $\omega_{1} \sim$ $\omega 3$ で除して求めた $h_{M k, j}$ の值をプロットしたものである。こられの図

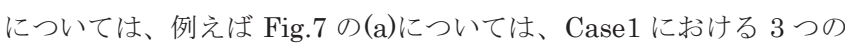

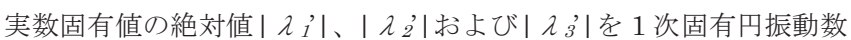
$\omega_{1}$ で除した值 $h_{M k, 1}$ をプロットした図であり、Fig.3 で 1 次粘性減衰 定数が求められた際のダンパーの状態をこれらの值が示しているこ とになる。すなわち、Fig.3において、1 次粘性減衰定数がピークを 迎える $\mathrm{n}=22$ の減衰係数の時、Fig.7(a)の $h_{M 1,1} 、 h_{M 2,1}$ および $h_{M 3,1}$ の 值は、図中に点線で示した $\mathrm{n}=22$ の線との交点の值となり、それぞれ 0.80、1.17、1.49 となっている。

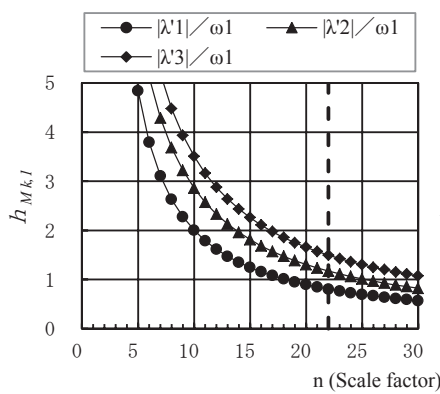

(a) $h_{M k, 1}$

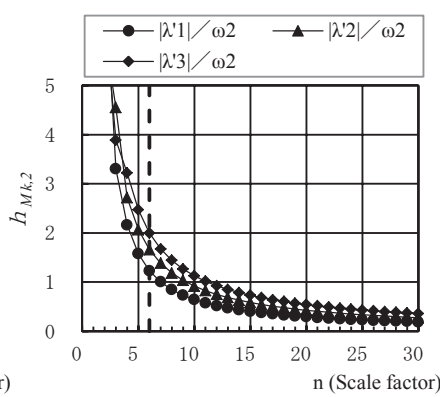

(b) $h_{M k, 2}$

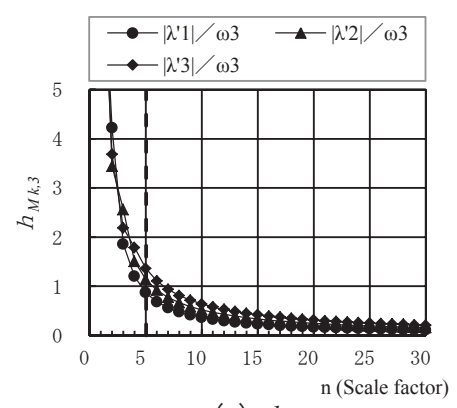

(c) $h_{M k, 3}$

Fig. 7 Parameters $h_{M k, j}$ of Maxwell dampers (Case1)

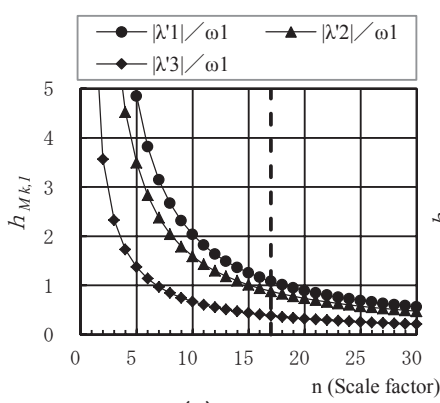

(a) $h_{M k, 1}$

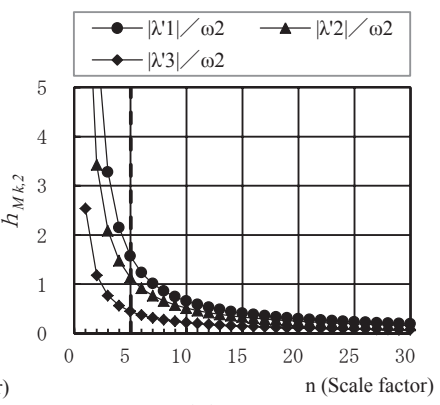

(b) $h_{M k, 2}$

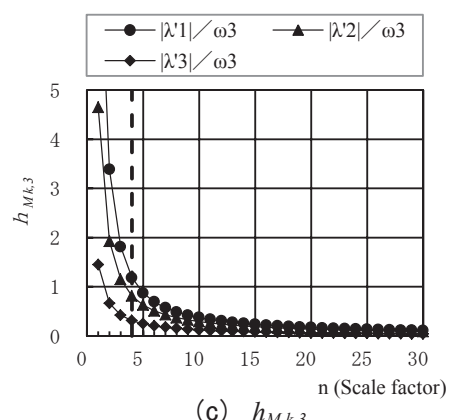

Fig. 8 Parameters $h_{M k, j}$ of Maxwell dampers (Case2)

前述したように、理論的にはこれらの值が全て 1.0 となるときに 粘性減衰定数が最大になるため、Fig. 3 における 1 次粘性減衰定数の ピーク值は調整次節でもう少し大きくなる可能性があるということ になる。同様に Fig.7(b)および(c)図において、Fig.3の 2 次および 3 次粘性減衰定数がピークを示す $\mathrm{n}=6$ および $\mathrm{n}=5$ の線との交点を求 めると、(b)図で 1.23、1.66、2.00、(c)図で 0.87、1.14、1.36 とな っており、(a)図と同様に調整次第で粘性減衰定数が大きくなる可能 性を示している。ただし、どの程度粘性減衰定数が大きくなるかは、 ダンパーが設置されている位置でのモード振幅の大小にも依存する 
ため、減衰係数調整後の固有值問題を解いて粘性減衰定数を算出す る必要がある。Fig.8 には、Case2 の場合の $h_{M k, j}$ を示してあるが、 減衰定数がピークを迎える時の $\mathrm{n}$ の值が Case 1 の事例と異なるだけ で、全体的に同様の傾向を示していることが分かる。次節では、 $h_{M k, j}$ の值が 1.0 に近づくように減衰係数を調整する方法について検討す る。

\section{3 固有值を用いた減衰係数の設定方法}

ここでは、仮定したダンパー配置でシステムの粘性減衰定数が最 大となるように減衰係数を決定する方法について、Fig.2 の平面骨 組モデルを対象に検討を行う。検討を行うにあたっては、粘性ダン パーの設置位置を前節と同様に 1 層、8 層および 15 層とする。そし て、各ダンパーの内部剛性 $k_{d}$ も前節と同様に Table 2 の值とする。 このような条件のもとで、 1 次、 2 次および 3 次の各粘性減衰定数 を対象として、各值が最大となるような $i$ 層の減衰係数 $C_{d i}$ の組み合 わせを、(6)式に示す反復計算で求めてみる。

$$
\begin{aligned}
& \text { 新 } C_{d i}=\frac{\left|\lambda_{k}^{\prime}\right|}{\omega_{j}} \cdot \text { 旧 } C_{d i} \\
& \text { ここで、 } \begin{aligned}
C_{d i}: \text { Damping coefficient of damper installed in the i-th floor } \\
\lambda_{k^{\prime}}: \text { Real eigenvalue of Maxwell damper } \\
\omega_{j}: \text { j-th modal circular frequency }
\end{aligned}
\end{aligned}
$$

（6)式を採用した理由について説明する。元々 $\lambda_{k}{ }^{\prime}$ は、前節で述心゙ たように、減衰係数の変化に対して単調性を示している。一方、固 有円振動数 $\omega_{j}$ の変化は非常に小さい。そこで、それらの性質をその まま利用して減衰を付加したい $j$ 次モードの固有円振動数 $\omega j$ に対し て、 $\left|\lambda_{k}{ }^{\prime}\right|$ が $\omega_{j}$ と同值になるような減衰係数を(6)式の形で簡便に求 めようとしたものである。そして、その(6)式による 5 回の反復計算 で求められた粘性減衰定数と各ダンパーの減衰係数を Table 3 に示 す。各ケースの粘性減衰定数の值は表中に示したように、1 次モ一 ドを対象にした場合が 0.056、2 次モードが 0.040、3 次モードが 0.075 となっている。Fig. 3 および Fig.4 の粘性減衰定数のピーク值 と比較すると、小数点以下第 3 位までの比較では、 2 次が一致、 1 次および 3 次は収斂計算結果のほうが大きくなっている。また、

Fig.3 における Case1 の粘性減衰定数がピークとなる時の減衰係数 の組み合わせを Table 4 に示す。両表を比較すると、各值は近いも のもあるが 2 倍近く異なっているものもあり、かなりばらついた結 果となっている。そこで、(5)式で求められる $h_{M k, j}$ の状況について 調べてみた結果を Fig.9 に示す。どのケースも 5 回の反復計算で值 が 1.0 に近くなっている状況が読み取れる。同図中、5 回の反復計 算終了時で最も数值が離れていたケースは、(a)図の入そで 1.12 であ った。Fig.7 および Fig.8 の場合と比較すれば、 $h_{M k, j}$ の值は十分に 1.0 に近づいており、粘性減衰定数もピーク值を捉えていることか ら、(6)式の計算により、対象としたモードの粘性減衰定数を最大に する減衰係数の組み合わせを、自動的に算出することに成功したと いえるだろう。一方で、Table 3 と Table 4 の值に不一致が見られる にも関わらず、得られた粘性減衰定数の值が Fig.3 および Fig.4の 結果とあまり変わらない理由に関して考察してみる。まず $h_{M k, j}$ の值 というのは、あくまでも設定した振動数でダンパーが最大の効果を 発揮できているか否かを判断する指標であり、各モードの粘性減衰
Table 3 Results of iterative computation

\begin{tabular}{|c|c|c|c|}
\hline \multirow{2}{*}{ Floor } & \multicolumn{3}{|c|}{ Computed damping coefficients $c_{d i}(\mathrm{kN} \cdot \mathrm{sec} / \mathrm{m})$} \\
\cline { 2 - 4 } & $\begin{array}{c}\text { Damping distribution } \\
\text { for the 1st mode } \\
h_{I}=0.056\end{array}$ & $\begin{array}{c}\text { Damping distribution } \\
\text { for the 2st mode } \\
h_{2}=0.040\end{array}$ & $\begin{array}{c}\text { Damping distribution } \\
\text { for the 3rd mode } \\
h_{3}=0.075\end{array}$ \\
\hline 15 & 16344 & 5626 & 3276 \\
\hline 8 & 36952 & 12599 & 8420 \\
\hline 1 & 46710 & 19242 & 11040 \\
\hline
\end{tabular}

Table 4 Damping coefficients for the peak values of viscous damping factor shown in Fig. 3 (Case1)

\begin{tabular}{|c|c|c|c|}
\hline \multirow{2}{*}{ Floor } & \multicolumn{3}{|c|}{ Damping coefficients in Fig.3 $c_{d i}(\mathrm{kN} \cdot \mathrm{sec} / \mathrm{m})$} \\
\cline { 2 - 4 } & $\begin{array}{c}\text { Damping distribution } \\
\text { for the 1st mode } \\
(\mathrm{n}=22)\end{array}$ & $\begin{array}{c}\text { Damping distribution } \\
\text { for the 2nd mode } \\
(\mathrm{n}=6)\end{array}$ & $\begin{array}{c}\text { Damping distribution } \\
\text { for the 3rd mode } \\
(\mathrm{n}=5)\end{array}$ \\
\hline 15 & 11000 & 3000 & 2500 \\
\hline 8 & 33000 & 9000 & 7500 \\
\hline 1 & 55000 & 15000 & 12500 \\
\hline
\end{tabular}

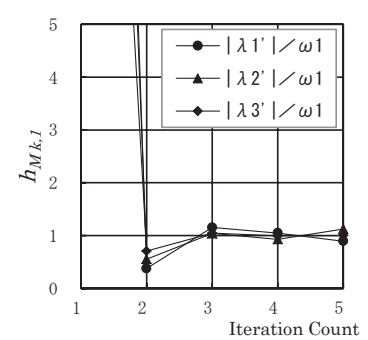

(a) Damping distribution for the 1st mode

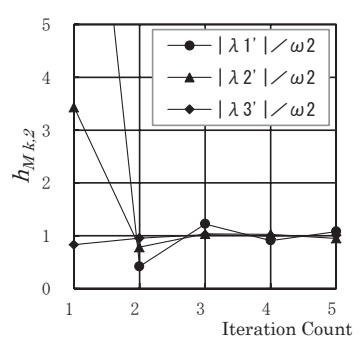

(b) Damping distribution for the 2nd mode

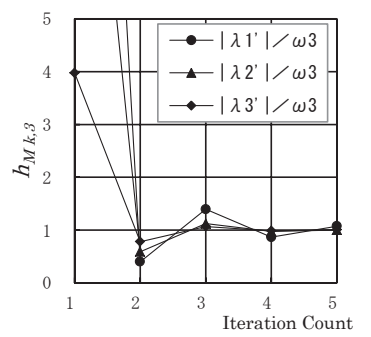

(c) Damping distribution for the 3rd mode

Fig. 9 Results of iterative computation

定数がどのくらい増えるかという情報は含まれていないということ が挙げられる。すなわち、Table 4 の減衰係数が適正值より大きく 外れたとしても、構造物全体の減衰性能にあまり影響しないような 場所に配置されていれば、結果として粘性減衰定数にはあまり変化 が無いということになる。また、別の理由として Fig.3 と Fig.4の 横軸は Table2 の係数倍という大きな值の変化があるにも関わらず、 減衰定数のピーク付近は割と緩やかに変化していることも挙げられ るだろう。当然、これは解析モデルや対象モードによって異なる性 状を示寸思われるため、あくまでも本検討における条件の場合に限 られる理由になる。結局、本モデルの場合は Fig.3 および Fig.4 の ケースと設置位置を変えないという条件で $h_{M k, j}$ を 1.0 に近づけてい るので、Fig. 3 および Fig.4 の粘性減衰定数の值を下回ることはない けれども、小数点以下第 3 位までの比較ではそれほど増加もしなか ったということである。

次に、実用上は Fig.9 程度の収斂結果で十分であるものの、減衰 係数の変化に対して単調性を示している固有值 $\lambda_{k}{ }^{\prime}$ の反復計算で収 斂しない原因について述べる。その理由としては、求められる固有 


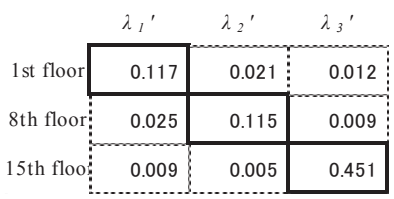

(a) Damping distribution for the 1st mode

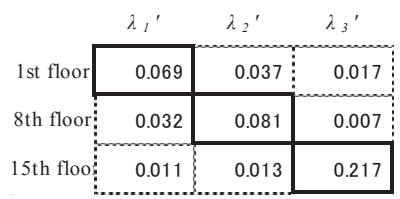

(b) Damping distribution for the 2nd mode

\begin{tabular}{c|c|c|c|}
\multicolumn{1}{c}{} & \multicolumn{1}{c}{$\lambda_{1}{ }^{\prime}$} & \multicolumn{1}{c}{$\lambda_{2}{ }^{\prime}$} & \multicolumn{1}{c}{$\lambda_{3}{ }^{\prime}$} \\
\cline { 2 - 4 } 1st floor & 0.054 & 0.018 & 0.017 \\
\cline { 2 - 3 } 8th floor & 0.015 & 0.066 & 0.049 \\
\hline 15th floo & 0.002 & 0.068 & 0.124 \\
\hline
\end{tabular}

(c) Damping distribution for the 3rd mode

Fig. 10 Eigenvectors in the five times iteration

值とダンパーの特性值とは 1 対 1 の独立な関係ではなく、3 層のダ

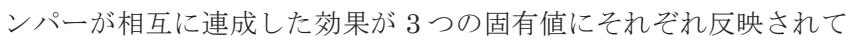
いるということが挙げられる。すなわち、ひとつのダンパーの減衰 係数を変えれば 3 つの固有值が変化することになる。そのため、3 基のダンパーを一度に収斂させたい場合には、入力する減衰係数と 固有值 $\lambda_{k}$ との関係を探りながら(6)式を適用する必要がある。本検 討においては、Fig.9 の反復計算を行うにあたって、固有值とダン パーとの関係を見極めるために、固有ベクトルの大きさを指標とし て判断している。その一例として、Fig.10に反復計算 5 回目の固有 ベクトルの值を示す。図中の各值は、(3)式の固有值問題より得られ る固有関数行列から、ダンパー変位と固有值との関連を示寸部分行 列の内容を抜き出したものである。Fig.10から、各ダンパーと固有 值との関連性は、固有ベクトルの大小で明確に判断できるため、そ の值の大きさから固有值と最も関連性の強いダンパーを決定するこ とが可能であることが分かる。その結果として、Fig.9 のような収 束状況にすることができたといえる。理論的には、す心゙ての $h_{M k, i}$ が 1.0 になる場合が減衰定数のピーク值となるが、前述したように それほどシビアに $h_{M k, j}$ を調整しなくても実用上は十分な精度が得 られる結果となっている。しかし、ダンパーの設置数が増え、ダン パー相互の影響が大きくなれば、全く収斂しない場合や(6)式の反復 計算の誤差が大きくなる場合も想定される。そこで本論では、配置 計画を行った全てのダンパーの減衰係数を同時に算出するための収 斂計算法を考案するよりも、実務への適用を重点において、ダンパ 一の配置位置による減衰性能の差異を判別しながら、より確実にダ ンパーの減衰係数を設定する手法について、次節で検討を行うこと にする。

\section{4 ダンパー1 基ごとに減衰係数を決定していく方法}

前節では、設置した複数のダンパーの減衰係数を反復計算により 一度に決定する方法を提案した。本節では、より実用的で確実に反 復計算が収斂する方法を提案する。その方法は、解析モデルに設置 するダンパーを 1 基のみと限定しておき、複数のダンパーを設置す る場合には、単独の結果を累加して最終的な減衰係数を決定する方 法である。例えば、Fig.2 の骨組モデルを用いて、前節と同様に Table 2 の配置でダンパーを設置する場合、Fig.11 に示すような流れで減 衰係数を決定することになる。まず 1 層にダンパーを設置した Model-A の減衰係数を反復計算で決定し、次に Model-B を決定、 最後に Model-C を決定するという 3 回の反復計算を実施する。そし

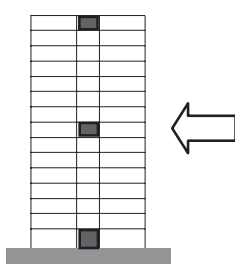

Mode I-D

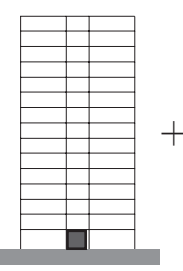

Mode I-A

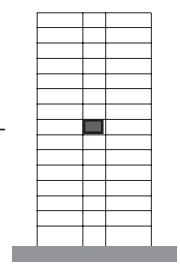

Mode I-B

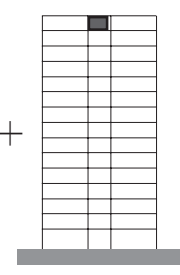

Mode I-C
Fig. 11 Computation of damping coefficients of Maxwell dampers

Table 5 Viscous damping coefficients computed by results of the models with one damper

\begin{tabular}{|c|c|c|c|}
\hline \multirow{2}{*}{ Floor } & \multicolumn{3}{|c|}{ Computed damping coefficients $c_{d i}(\mathrm{kN} \cdot \mathrm{sec} / \mathrm{m})$} \\
\cline { 2 - 4 } & $\begin{array}{c}\text { Damping distribution } \\
\text { for the 1st mode }\end{array}$ & $\begin{array}{c}\text { Damping distribution } \\
\text { for the 2nd mode }\end{array}$ & $\begin{array}{c}\text { Damping distribution } \\
\text { for the 3rd mode }\end{array}$ \\
\hline 15 & 17185 & 5878 & 3500 \\
\hline 8 & 38971 & 14397 & 8703 \\
\hline 1 & 46177 & 17746 & 11597 \\
\hline
\end{tabular}

Table 6 Modal viscous damping factors (Model-A, B, C, D)

\begin{tabular}{|c|c|c|c|}
\hline $\begin{array}{c}\text { Analytical } \\
\text { model }\end{array}$ & $\begin{array}{c}\text { Damping distribution } \\
\text { for the 1st mode } \\
\mathrm{h}_{1}\end{array}$ & $\begin{array}{c}\text { Damping distribution } \\
\text { for the 2nd mode } \\
\mathrm{h}_{2}\end{array}$ & $\begin{array}{c}\text { Damping distribution } \\
\text { for the 3rd mode } \\
\mathrm{h}_{3}\end{array}$ \\
\hline Model-A & 0.026 & 0.032 & 0.028 \\
\hline Model-B & 0.024 & 0.008 & 0.026 \\
\hline Model-C & 0.001 & 0.004 & 0.006 \\
\hline \hline $\begin{array}{c}\text { sum total } \\
\text { (A+B+C) }\end{array}$ & 0.051 & 0.043 & 0.060 \\
\hline \hline Model-D & 0.056 & 0.040 & 0.075 \\
\hline \hline $\begin{array}{c}\text { Ratio } \\
(\mathrm{A}+\mathrm{B}+\mathrm{C}) / \mathrm{D}\end{array}$ & 0.907 & 1.075 & 0.800 \\
\hline
\end{tabular}

Table 7 Parameters of Maxwell dampers $h_{M k, j}$ (Mode I- D)

\begin{tabular}{|c|c|c|c|}
\hline & $\begin{array}{c}\text { Damping distribution } \\
\text { for the 1st mode } \\
\left|\lambda^{\prime}{ }_{k}\right| / \omega_{1}\end{array}$ & $\begin{array}{c}\text { Damping distribution } \\
\text { for the 2nd mode } \\
\left|\lambda^{\prime}{ }_{k}\right| / \omega_{2}\end{array}$ & $\begin{array}{c}\text { Damping distribution } \\
\text { for the 3rd mode } \\
\left|\lambda^{\prime}{ }_{k}\right| / \omega_{3}\end{array}$ \\
\hline$h_{M 1, j}$ & 1.019 & 1.026 & 0.971 \\
\hline$h_{M 2, j}$ & 0.934 & 0.924 & 0.931 \\
\hline$h_{M 3, j}$ & 0.950 & 0.956 & 0.925 \\
\hline
\end{tabular}

て、各計算で求められた減衰係数を Model-D に設定して、最終的な 粘性減衰定数を求めるという方法である。

以上の方法によって、1 次〜3 次までの各振動モードを対象にし て求められた各層のダンパーの減衰係数を Table 5 に示す。また、 算出過程での各モデル（Model-A、B、C、D）で求められた粘性減 衰定数を Table 6 に示す。最終的にダンパー3 基を設置した Model-D の粘性減衰定数は、Table 6 の下から 2 段目に記してあり、1 次を 対象にした場合が $h_{1}=0.056 、 2$ 次を対象にした場合が $h_{2}=0.040 、 3$ 次を対象にした場合が $h_{3}=0.075$ と求められている。この值は、 3 基の減衰係数を一度で求めた前節の結果と同じ値となっている。ま た、各層の減衰係数の值も Table 3 と Table 5 の比較から、両者は 近い值となっており、ダンパー相互の干渉を無視した計算から求め られた減衰係数によっても、ほぼ同様の結果を得ることができてい る。このような決定方法を用いると、解析ケースは増えるものの、 前節のようなダンパーと固有值 $\lambda_{k}{ }^{\prime}$ の関連性を調べるような作業が 不要であるため、（6)式の $\lambda_{k} / \omega_{j}$ は確実に 1.0 に収斂する。 


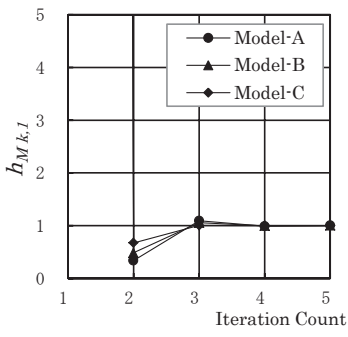

(a) Damping distribution for the 1st mode

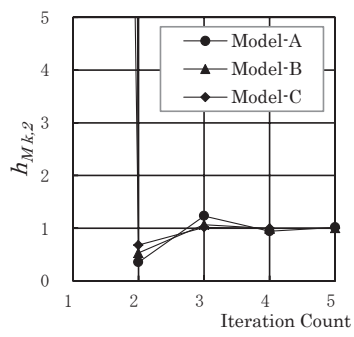

(b) Damping distribution for the 2nd mode

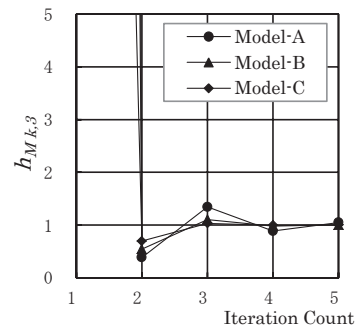

(c) Damping distribution for the 3rd mode

Fig. 12 Results of iterative computation using one damper models (Model-A, B, C)

また前節で述べたように、各ダンパーが建物に付与できる減衰性 能を知るためには、粘性減衰定数を調べる必要があるため、本検討 のように 1 基ずつ計算を行っておけば、その過程で各ダンパーが建 物に付与できる最大の減衰性能が明らかとなり、配置計画を行う際 の有効な資料になるという利点もある。例えば、Table 6 の 1 次モ ードを対象にした結果の中で、Model-C（最上階に設置）のダンパ 一は粘性減衰を $0.1 \%$ しか付与できず、他のダンパーよりも効果が低 いことが明確となるため、設置場所を変更するなどの対策がスムー ズに行えることになる。

次に、 $h_{M k, j}$ の収斂状況を Fig. 12 に示すが、全ケースとも 5 回の 反復計算で誤差 $1 \%$ 未満となっており、確実で安定した反復計算を 行うことが可能である。しかし、それら $h_{M k, j}$ の值は、Model-D に設 定された時には当然 1.0 の值から外れることになる。Table 7 にそ の $h_{M k, j}$ の值を示すが、全体の傾向からすると 1.0 を下回っている值 の方が多くなっている。これは、各ダンパーに設定されている減衰 係数が大きすぎることを示しており、ダンパー間の連成による効果 を考慮に入れる場合には、これらの值を参考にして減衰係数を再設 定することも可能であろう。しかし、Table 7 程度の差異であれば、 前節までの結果と同様に、粘性減衰定数の值がほぼ最大の状態であ るため、そのような作業は不要であろう。一方で、Table 6 におけ る Model-A、B および C の粘性減衰定数を単純和した值と Model-D の值との差異は、Table 6 の最下段に示されているように、最大で 2 割程度生じているため、最終的には累加計算ではなく複数のダンパ 一を設置した状態で、粘性減衰定数を計算しておく必要性を示唆す る結果となっている。

最後に Model-D の水平方向 $1 \sim 3$ 次の粘性減衰定数を Table 8 に、 水平方向絶対加速度の応答倍率曲線を Fig.13、Fig.14 および Fig.15 に示すことによって、各モデルの特性をまとめておく。なお、応答 倍率は最上階の水平加速度の絶対值を入力加速度の絶対值で除すこ とにより求めている。各図とも本検討で対象としてきた 3 次までの 振動モードが出力される周波数範囲を抜き出してあるが、 $3.5 \mathrm{~Hz}$ 付
Table 8 Modal viscous damping factors $h_{j}$ (Model-D)

\begin{tabular}{|c|c|c|c|}
\hline & $\begin{array}{c}\text { Damping distribution } \\
\text { for the 1st mode }\end{array}$ & $\begin{array}{c}\text { Damping distribution } \\
\text { for the 2nd mode }\end{array}$ & $\begin{array}{c}\text { Damping distribution } \\
\text { for the 3rd mode }\end{array}$ \\
\hline$h_{1}$ & 0.056 & 0.034 & 0.023 \\
\hline$h_{2}$ & 0.022 & 0.040 & 0.040 \\
\hline$h_{3}$ & 0.026 & 0.062 & 0.075 \\
\hline
\end{tabular}

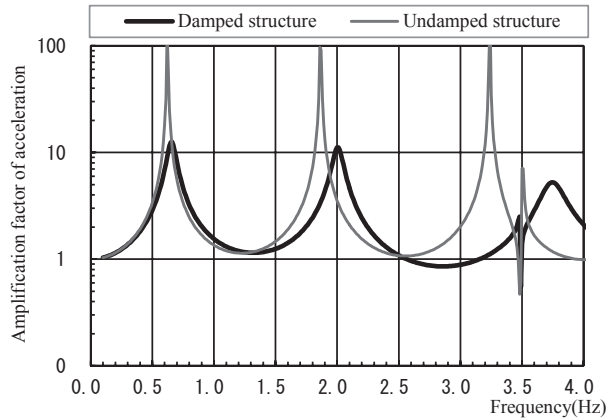

Fig. 13 Amplification factor of absolute acceleration of design model for the 1st mode

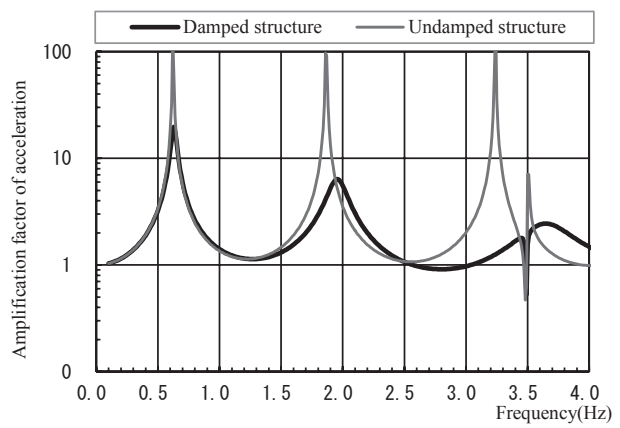

Fig. 14 Amplification factor of absolute acceleration of design model for the 2nd mode

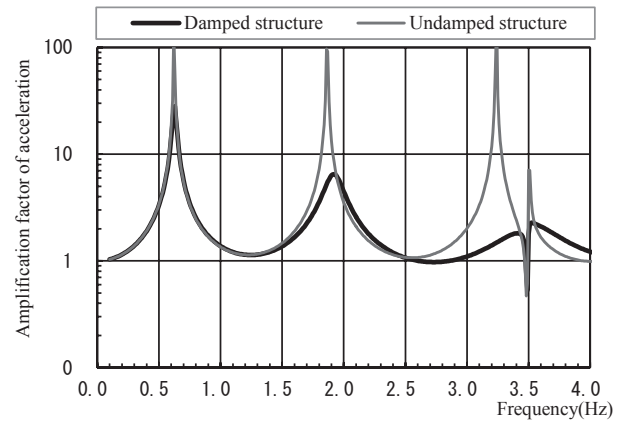

Fig. 15 Amplification factor of absolute acceleration of design model for the 3rd mode

近にもそれ以外のピークが見られる。この振動モードは、上下振動 が優勢なモードであるが、 $3.2 \mathrm{~Hz}$ 付近の水平 3 次の振動モードと連 成しており、ダンパー設置後はさらにその連成度合が強まるような 状態となっている。骨組モデルを採用しているため、そのような状 態となるのはやむを得ないが、各図におけるピークをTable 8 と単 純に比較してみると、制振対象とした振動モードの応答倍率が小さ くなっていることが分かる。Fig.14 および Fig.15 においては、設 定された減衰係数の值が割と近いこともあり、2 次および 3 次の二 つのモードに同時に効果が表れている結果となっている。特に、今 
回の配置では 3 次モードの粘性減衰定数の值が最も大きくなってお り、ダンパー配置位置の違いによりその効果が大きく異なってくる ことを改めて確認することができる。Fig.13においては、Table 8 の值と比較すると、2 次および 3 次のピーク值が 1 次のピーク值に 比べてもっと大きくなっても良さそうであるが、これは倍率を算出 している最上階という位置の忘答性状が表れたものであり、別の位 置で応答倍率を算出寸れば、また別の結果が表れることになる。本 研究で提案した手法は、ターゲットとする振動数がひとつだけであ るため、ある振動モードを対象に粘性ダンパーの減衰係数を決定す れば、当然他のモードの応答にも影響を及ぼすことになる。このよ うに、複数振動モードの影響や応答性状まで含めて考えれば、配置 計画は非常に煩雑な作業になることは明らかである。本研究で提案 した手法が、そのような煩雑な作業の一助になるように、今後はよ り多くのモデルに対して適用性の検討を行っていく予定である。

\section{4. まとめ}

Mawell 型減衰要素のダッシュポット部分の変位を考慮に入れた 固有值を用いて、任意のモードに対する粘性減衰定数が最大になる ように粘性ダンパーの減衰係数を決定する方法を提案し、その有効 性を確認した。その結果と考察を以下にまとめる。

1 ）線形な粘性ダンパーを対象にして、ダンパーの内部剛性を仮定 したのちの減衰係数の決定方法を示寸ことができた。本論で示 した方法をまとめると、(1)ダンパーの減衰係数をパラメトリッ クに変化せて減衰定数のピークを探る方法、(2) $h_{M k, j}$ の值が 1.0 になるように、一度に全てのダンパーの係数を収斂計算で求め る方法、(3) $h_{M k, j}$ の值が 1.0 になるように、一基ずつダンパーの 減衰係数を収斂計算で求める方法、以上の 3 種類である。いず れの方法によっても概ね同様な減衰定数值が得られているため、 今回のモデルでは実用上十分な精度でピークを捉えることがで きたと考えている。また、実際の製品では内部剛性と減衰係数 の組み合わせは限られており、計算結果がそのまま適用できる ことは少ないと思われる。計算で求められた減衰係数と大きく 異なるような製品を選択せざるを得ない場合には、 $h_{M k, j}$ の值が 1.0 を上回るように製品を選択したほうが、エネルギー吸収性 能は効率的になることが既往の研究 8)で明らかとなっている。

2 ）対象とした平面骨組モデルは一例だけであるが、部材レベルで のマトリックス解析を基本としているために、立体骨組や質点 一ばね系などの様々なモデルにも適用可能である。ただし、反 復計算の精度等については対象とするモデルによって差が生じ ると考えている。今後の検討課題としたい。

3 ) 本検討では、制振対象とする振動モードを限定し、その対象モ 一ドの粘性減衰定数が最大になるような減衰係数決定方法を示 すことができた。しかし、実際の設計においては、複数のモー ドの影響や実地震動による応答など、さらに様々な要因を考慮 に入れたうえでダンパーの配置や仕様を決定しなければならな い。そのため、今回の検討結果だけをもって構造物の最適な減 衰係数分布について言及するつもりはない。今後、より多くの モデルに対して本手法を適用しながら研究を進め、多くの知見 をまとめたうえで、改めて最適な減衰係数分布について考えて みたい。

\section{参考文献}

1) パッシブ制振構造設計・施工マニュアル 第 3 版, 日本免震構造協会, 2013.11 2) 蔭山満, 背戸一登 : 定点理論に基づく制振計画法に関する研究, 日本建築学 会大会学術講演梗概集，B-2，構造 II，pp.1007-1008，2005.9

3) 安井譲: Maxwell 型の層間ダンパーを有する多質点系モデルの定点に関する一 考察, 日本建築学会構造系論文集, 第 620 号, pp.27-34, 2007.10

4) 松田敏: Maxwell 型粘性ダンパーを有する構造物の統計的等価減衰定数に基づ く最適設計，日本建築学会構造系論文集，第667 号, pp.1649-1657, 2011.9

5) 石井正人, 北村春幸, 和田章, 笠井和彦 : 粘弾性型制振部材付き架構のモデ ル化に関する検討，日本建築学会構造系論文集，第 531 号，pp.55-62，2000.5

6) 竹内徹, 市川康, 中島秀雄, 笠井和彦: ダンパーが不均等配置された多層パッ シブ制振構造の応答予測, 日本建築学会構造系論文集, 第 583 号, pp.115-122, 2004.9

7) 西村功: 構造物内部に設置された減衰装置の性能評価, 日本建築学会構造系 論文集，第 579 号, pp.23-30, 2004.5

8) 石垣秀典, 石丸辰治 : マックスウェルモデルで模擬されるパッシブ型制震構 造物の性能評価法- 1 質点粘性減衰系を対象にした検討一, 日本建築学会構造 系論文集，第597号，pp.55-61，2005.11 


\title{
STUDY ON DAMPING DISTRIBUTION OF MAXWELL-TYPE VISCOUS DAMPERS BASED ON EIGENVALUE ANALYSIS
}

\section{Hidenori ISHIGAKI*}

\author{
* IES Corporation, Dr. Eng.
}

It is very difficult to determine viscous damper distribution of a frame structure so as to have the maximum energy dissipation performance. So properties and arrangements of dampers are determined by trial and error response analysis in many practical designs. In such a situation, this paper presents a passive control design of building structures with Maxwell-type viscous dampers. Many of previous studies have proposed design methods of damping devices using mass-spring models. As a consequence, to apply the results of those studies became difficult in many practical designs. Therefore, a design method using eigenvalue analysis is proposed in this study, so as to compute properties and distribution of viscous dampers automatically.

Generally, a single mass-spring system with Maxwell model has three degrees of freedom. That is, the three eigenvalues are derived, in which the two are conjugate complex numbers $\lambda_{1}$ and $\bar{\lambda}_{1}$, and the other is real number $\lambda_{1}{ }^{\prime}$. The real number eigenvalue has dynamic characteristics of Maxwell model. For example, the value contains the property of setting positions, attachment members and energy dissipation of the viscous dampers. And if the real number eigenvalue is equal to a natural circular frequency of damped structure, the structure will have the maximum viscous damping factor to the vibration mode. Therefore, it can be possible to determine damper distribution automatically by the iterative calculation based on the characteristic feature.

In the case of $\mathrm{N}$-degrees of freedom model with $\mathrm{M}$-set viscous dampers, the eigenvalues of $2 \mathrm{~N}$ conjugate numbers and $\mathrm{M}$ real numbers are derived (Eq. (4)). In this paper the design method is performed by 15 -story frame structure shown in Fig. 2. From the First natural period to the third natural period of the analysis model are $1.60 \mathrm{sec}, 0.53 \mathrm{sec}$ and $0.46 \mathrm{sec}$. In the case of viscous dampers installed in the $1^{\text {st }}$ floor, the $8^{\text {th }}$ floor and the $15^{\text {th }}$ floor, the maximum viscous damping factors are calculated by trial and error method which is the method of changing damping coefficients and calculating viscous damping factors repeatedly (Fig. 3 ). And the viscous damping factors are 0.055 as the $1^{\text {st }}$ mode, 0.04 as the $2^{\text {nd }}$ mode, 0.073 as the $3^{\text {rd }}$ mode shown in Fig. 3. By using the proposed method, it has been investigated whether it is possible to calculate the damping coefficients such that the viscous damping factor calculated by trial and error method (Fig.3). There are two methods for calculating the damping coefficients of the dampers. One is the method of calculating three dampers simultaneously. The other is the method of calculating three dampers separately (Fig. 11). These two methods have been performed, and the results showed that both of the methods can reproduce the value calculated by trial and error method (Table 3 and Table 5). The iteration count in one simulation is less than 5 times (Fig. 9 and Fig. 12), and the results have been computed automatically by this proposed method. Moreover, it has been showed that the differences of the energy dissipation by damper distribution are clarified by this method. From those results, it became clear that these methods are applicable to practical design for passive control buildings. 